\title{
Central Role of Innate B-Cell Immunity in Cancer Prevention
}

\author{
Nikolay Tupitsyn \\ Federal State Budgetary Institute "N. N. Blokhin National Medical Research Center of Oncology" of the Ministry of Health of \\ Russia, Moscow, Russia \\ Email:nntca@yahoo.com
}

How to cite this paper: Tupitsyn, N. (2021) Central Role of Innate B-Cell Immunity in Cancer Prevention. Advances in Biological Chemistry, 11, 12-14. https://doi.org/10.4236/abc.2021.111002

Received: May 28, 2020

Accepted: January 30, 2021

Published: February 2, 2021

Copyright (c) 2021 by author(s) and Scientific Research Publishing Inc. This work is licensed under the Creative Commons Attribution International License (CC BY 4.0).

http://creativecommons.org/licenses/by/4.0/

\begin{abstract}
There are some forgotten items. There is a specific way to eradicate cancer cells at the very early stage of their appearance. Natural humoral immunity with $\mathrm{CD} 5+\mathrm{B}$-cell produced pentameric IgM to cancer associated glycans normally to eliminate arising cancer cells. This branch of innate immunity is decreasing with age and that is a basis for selective immunodeficieny which may be corrected. This area of research was well studied and proved by the team of Prof. Vollmers (Germany), but then forgotten for about 15 years.
\end{abstract}

\section{Keywords}

Natural B-Cell Immunity, Cancer Prevention, IgM, Anti-Glycans

There are perspectives to win cancer, but with each year those perspectives become more and more unfeasible. The serious attempts to cure cancer, to eradicate it are in the past.

It is very important to formulate the strategy task and to refuse some "absolute doctrines". One of them is related to the role of immune system in cancer. The chief oncologist of Russia academician, Professor Mikhail Davydov thinks that "There is no cancer immunology, it is mere infectional immunology" [1]. He noted "It is important to remember one thing: once the body misses the tumor, it will never catch it up again, whatever the immunity status or lymphocyte tumor tissue infiltration". As well, he outlined ways of most perspective anticancer fighting-natural antibodies against tumor-associated glycans. In other words, the centrum of anticancer fighting is suggested to move from adaptive immunity to natural immunity, from T-cell immunity to humoral immunity, and from cancer treatment to cancer prevention.

Is it possible to win cancer? Surely not each oncologist will answer "Yes". The 
problem is that it seems to be no selective drug capable to kill tumor cells, not destroying normal cells. Is that really so? The answer is "NO". The selective method of cancer cell elimination exists!

That method is the induction of lipoapoptosis (sometimes called lipoptosis) with anti-tumor-associated glycans which combine high specificity of pentameric IgM antibodies to that glycans with the capacity of the antibodies to transport lipids into tumor cell. Lipid accumulation induces cancer cell death. German scientists achieved the main successes in that area about 15 years ago [2] [3] [4].

Tumor-associated glycans are very good targets for selective tumor cell elimination. There are about 70 such glycans. Natural pentameric IgM antibodies to that glycans are making control on transformed cells. With ageing levels of such antibodies decline and are lower in cancer patients than in healthy persons. This is a basis for selective immunodeficiences [5]. Antibody immunodeficiency to tumor-associated glycan $\mathrm{Le}^{\mathrm{C}}$ in $\mathrm{Le}^{\mathrm{c}}$-positive breast cancer patients proved to be in $35 \%$ of cases [6].

Anti-glycan profiles diagnosed with glycochips (printed glycan arrays) allow to diagnose cancer much earlier ( 3 - 4 years earlier) than standard procedures, and it gives possibilities for correction of antibody levels before cancer arises or at very early stages of cancer. One of such examples is known in lung cancer arising in smokers [7]. The specific anti-glycan profiles are proved for several types of cancer. Lipoapoptosis seems to be the main mechanism of cancer prevention.

So, cancer is hardly curable but preventable disease. The idea to win cancer should be the strategy of oncology. Tactical task in that case is the identification of cancer-specific anti-glycan profiles in cancer risk groups and correction of those immunodeficiences.

The aim of this paper is to attract attention to the strategy of oncology-eradication of cancer as a disease and as a social problem. The antiglycan approach is very useful not only in prevention of cancer but in cancer patients as well as selective eradication of disseminated tumor cells from bone marrow [8], which to our mind is the most important problem in cancer patients [9] [10]. Innate immunity is, in contrast to the adapted immunity, not trainable. So, attempts to find immunoajuvants for its elevation may be very perspective [11].

\section{Conflicts of Interest}

The author declares no conflicts of interest regarding the publication of this paper.

\section{References}

[1] Davydov, M.I. (2017) There is No Cancer Immunology, It is Mere Infectional Immunology. Haematopoiesis Immunology, 15, 10-11.

[2] Brandlein, S., Pohle, T., Ruoff, N., Wozniak, E., Muller-Hermelink, H.K. and Vollmers, H.P. (2003) Natural IgM Antibodies and Immunosurveillance Mechanisms against Epithelial Cancer Cells in Humans. Cancer Research, 63, 7995-8005. 
[3] Pohle, T., Brandlein, S., Ruoff, N., Muller-Hermelink, H.K. and Vollmers, H.P. (2004) Lipoptosis: Tumor-Specific Cell Death by Antibody-Induced Intercellular Lipid Accumulation. Cancer Research, 64, 3900-3906. https://doi.org/10.1158/0008-5472.CAN-03-3149

[4] Brandlein, S., Rauschert, N., Rasche, L., Dreykluft, A., Hensel, F., Conzelmann, E., Muller-Hermelink, H.K. and Vollmers, H.P. (2007) The Human IgM Antibody SAM-6 Induces Tumor-Specific Apoptosis with Oxidized Low-Density Lipoprotein. Molecular Cancer Therapeutics, 6, 326-333. https://doi.org/10.1158/1535-7163.MCT-06-0399

[5] Tupitsyn, N.N., Galanina, O.T., Bovin, N.V, Gadetskaya, N.A., Shelepova, V.M., Korotkova, O.V. and Kadagidze, Z.G. (2008) Level of Specific Antibodies to Glycan $\mathrm{Le}^{\mathrm{C}}$ is Diminished in Breast Cancer Patients. Immunologia, 2, 31-33.

[6] Tupitsyn, N.N., Udalova, Y.A., Galanina, O.E., Kadagidze, Z.G., Borovkova, N.B., Podolsky, V.V., Shinkarev, S.A., Gadetskaya, N.A., Letyagin, V.P., Obukhova, P.S., Shilova, N.V., Subbotina, A.A. and Bovin, N.V. (2009) Tumor-Associated Glycan Lewis $\mathrm{C}$ in Breast Cancer. Haematopoiesis Immunology, 6, 45-54.

[7] Huflejt, M. (2019) Glyco-Immuno-Oncology: From Diagnosis to Treatment Opportunities. http://imhaemo.ru/media/documents/HI_16/28_16.pdf

[8] Illert, B., Otto, C., Vollmers, H.P., Hensel, F., Thiede, A. and Timmermann, W. (2005) Human Antibody SC-1 Reduces Disseminated Tumor Cells in Nude Mice with Human Gastric Cancer. Oncology Reports, 13, 765-770. https://doi.org/10.3892/or.13.4.765

[9] Zheng, H., Bae, Y., Kasimir-bauer, S., Tang, R., Chen, J., Ren, G., Yuan, M., Esposito, M., Li, W., Mei, Y., Shen, M., Zhang, L., Tupitsyn, N., Pantel, K., King, C., Sun, J., Moriguchi, J., Jun, H.T., Coxon, A., Lee, B. and Kang, Y. (2017) Therapeutic Antibody Targeting Tumor and Osteoblastic Niche-Derived Jagged1 Sensitizes Bone Metastasis to Chemotherapy. Cancer Cell, 32, 731-747.

https://doi.org/10.1016/j.ccell.2017.11.002

[10] Chernysheva, O., Markina, I., Demidov, L., Kupryshina, L., Chulkova, S., Palladina, A., Antipova, A. and Tupitsyn, N. (2019) Bone Marrow Involvement in Melanoma. Potentials for Detection of Disseminated Tumor Cells and Characterization of Their Subsets by Flow Cytometry. Cells, 8, 627. https://doi.org/10.3390/cells8060627 https://www.mdpi.com/journal/cells

[11] Alexia, C., Cren, M., Louis-Prence, P., Vo, D.N., El-Ahmadi, Y., Dufourcq-Lopez, E., Lu, Z., Hernandez, J., Shamilov, F., Chernysheva, O., Vasilieva, M., Vorotnikov, I., Vishnevskay, Y., Tupitsyn, N., Rossi, J.F. and Villaba, M. (2019) Polyoxidonium Activates Cytotoxic Lymphocyte Responses through Dendritic Cell Maturation: Clinical Effects in Breast Cancer. Frontiers in Immunology, 10, 2693.

https://doi.org/10.3389/fimmu.2019.02693 